\title{
Anmeldelser
}

\section{En ny skandinavisk Foucault}

Niels Brügger, Knut Ove Eliassen og Jens Erik Kristensen (red.): Foucaults masker, Forlaget Modtryk 1995, 214 sider illst., $125,-\mathrm{kr}$.

*

Det er ingen overdrivelse, at der findes hundredvis af "Foucault'er", filosofiske, historiske, sociologiske, politiske, seksuelle, astetiske og litteraturvidenskabelige. De sidste har glimret ved deres fravar i den skandinaviske debat, og det er bl.a. dette, denne norsk-danske antologi ønsker at råde bod på.

Problemet er især det, at Foucault ganske vist ofte inddrager og behandler kunstvarker i sit forfatterskab, men at han snarere tænker 'med' kunst end om den: udvalgte stykker kunst og litteratur påkaldes nasten besvargende som momenter af anderledeshed, topoi hinsides sproget og de gængse tænkningsregimer, uantastelige, mystiske og gådefulde vidnesbyrd om et 'rent' (i begge ordets betydninger) Andet. Kunsten har nærmest åbenbaringskarakter for Foucault, og det er nok en hovedgrund till, at netop litterater paradoksalt nok ofte er gået en stor bue om de eksplicit 'litteraturfilosofiske' aspekter hos Foucault.

Ved at tage udgangspunkt i 'marginalteksternes Foucault', især teksterne om litteratur og kunst, griber denne udgivelse modigt fat om nælden. Den rummer oversattelser (til dansk) af seks 'oversete' og besværlige Foucault-tekster, og efterfølgende analyser søger at vise hvordan disse tekster kaster nyt lys på forfatterskabet, altså skiftevis Foucault og analyse. Ganske i Foucaults ånd benyttes det tilsyneladende 'perifere' til at belyse det 'centrale'. Antologien er kronologisk opbygget, teksterne strækker fra 1963 til 1983.

Der lagges dristigt ud med to spændende, men også uhyre komplekse og vanskelige artikler, nemlig Bataille-analysen "Forord til overskridelsen" fra 1963 og Blanchotanalysen "Tænkningen af det udenfor" fra 1966. Her er der virkelig tale om 'besværlige' tekster, som den skandinaviske sekundærlitteratur som oftest har ignoreret, da de ikke passer ind i de gangse "Foucault'er".

De to kommentatorer, litteraterne Knut Ove Eliassen og Frederik Tygstrup, mestrer begge den vanskelige opgave at relatere og inkorporere disse tekster i "Foucault". Eliassen udvider i sin artikel "Mellom begjaret og skriften" Bataille-analysens søgen efter en ikke-human anderledeshed til hele forfatterskabet med dets fokus på tærskel-, grænse- og overskridelseserfaringer, især til studierne af "grænseerfaringerne" seksualitet, død og galskab. Han ser (ikke ganske uproblematisk) Bataille-analysen som et første forstudie til Seksualitetens historie, og dennes bestemmelse af seksualiteten som en profan negativ teologi: hvor Gud var, trader 'Kong Sex' ind. Mere overbevisende bestemmer han Foucaults anvendelse af galskaben som allegori på det diskursive Andet, og anfører Derridas kritik af den paradoksale foucaultske bestrabelse på i et ra- 


\section{Anmeldelser}

tionelt sprog at indfange det irrationelle: galskaben. If $\varnothing l$ lge Derrida ligger løsningen i Foucaults stil, pathos eller med andre ord i hans galskabshistories 'litterære dimension'. Man kan måske forsigtigt konkludere, at Foucault i sin indkredsning af det diskursive 'Andet' ikke blot påkalder litteraturen, men selv fors $ø$ ger at producere 'litteratur'.

Frederik Tygstrups artikel om "'Menneskets død' og den litterære erfaring", en af bogens bedste, indsætter på spændende vis den tidlige Foucaults litteraturvidenskabelige arbejder i en højmodernistisk, æstetisk kontekst. Foucaults egensindige omgang med (udvalgte) modernistiske tekster forbindes med hans tanker om sprogets væren (hvor subjektet kun kan genfinde sig selv som fremmed), og hans kritik af den moderne tænknings "antropocentriske tryllekreds", der i en refleksiv bevægelse sætter 'Mennesket' som al tænknings ophav og resultat; her karakteriseres den modernistiske litteratur, der deklamerer skriftens upersonlighed og forfatterens $\mathrm{d} \varnothing \mathrm{d}$, som "post-human" overskridelsesstrategi, erkendelsesmæssige mod-diskurser.

Sproget ses hos Foucault ikke som et "menneskesprog", men som et system, der sprænger subjektbegrebet: 'jeg'et' i sætningen "jeg taler" bliver ikke længere en agens, men en slags performans: "en subjektivitet, der falder sammen med talens begivenhed og ophører sammen med den" (s. 69). Således dechifrerer Tygstrup Foucaults indledning til Blanchot-artiklen: "Førhen rystede den graske sandhed alene ved denne bekræeftende påstand: "jeg lyver". "Jeg taler" sætter hele den moderne fiktion på prøve" (s. 47). Sproget har sin egen væren, ordene og tingene falder aldrig sammen, og det er i denne kl $\varnothing \mathrm{ft}$, at "det udenfor" kan åbenbare sig. Sproget er ikke noget menneskesprog, men mennesket er et sprogmenneske, det er ikke subjektet, der er herre over talen, har ordet i sin magt så at sige, men sproget der udstikker en række mulige subjektivitetspositioner.

Den moderne litteratur er i Tygstrups optik det priviligerede sted for afsløringen af sprogets upersonlighed: "Dermed bliver det litterære univers et medium for 'umulige' erfaringer, en maskine, der kan satte den eksistentielle subjektivitet ud af kraft og indsætte den skrivende i et erfaringsunivers, der lyder andre regler end dem, som tanken og den dagligdags erfaring giver adgang til" (s. 69). Her har den strukturfællesskab med den foucaultske galskab. Disse to former kan vriste endelighedserfaringen fri af den transcendentale narcissisme, den antropologiske cirkel med dens evindelige fokuseren på mennesket, der ifølge Foucault hærger vores moderne "épisteme", og bidrage til en konfrontation med endeligheden som moderne eksistensbetingelse.

Den moderne litterære erfaring indeholder således langt mere end 'forfatterens død', den udfordrer hele opfattelsen af det transcendentale subjekt, 'det menneskelige' bliver højst et slags spildprodukt i den litterære procedure: "Den litterære erfarings subjekt er en 'ingen', en 'nulperson', som netop i denne egenskab kan bidrage til at tegne figurer i et endeligt, ubegrænset og fundamentalt umenneskeligt univers" (s. 81), som det hedder med en af de for Tygstrup så karakte- 


\section{Anmeldelser}

ristiske spidsformuleringer.

Den næste artikel, Foucaults berømte analyse af Velasquez' maleri, "Las Meninas", genlaeser man gerne, men teksten er ingenlunde marginal (den udgør første kapitel af hovedværket Les mots et les choses), og Arnfinn B $\varnothing$-Ryggs essay (antologiens længste), som betoner Foucaults betydning for kunsthistorien og omvendt, er både traditionelt og sludrende. F.eks. tillagges Foucault en normativ astetik om den sande, selvafkraftende kunst: "Forutsetningen er at man i sitt kunstneriske virke hverken går ut fra en teori eller lar det skapende arbeid gå opp i håndverksmessig kyndighet" (s. 103). Her er det vist den norske kunsthistoriker, der lagger Foucault sine egne idiosynkrasier i munden. Artiklen slutter med en parafrase af Foucaults lille spøjse analyse af Magrittes berømte (ikke-)pibebillede; den havde man gerne set i dansk oversattelse.

Heller ikke den næste Foucault-tekst, interviewet "Sandheden, magten og den intellektuelle" (som falder helt uden for temaet om den 'æestetiske' Foucault) bringer nye aspekter ind i den skandinaviske diskussion, og Niels Brüggers sammenligning af 'den intellektuelle' hos Foucault og Sartre er underlig tynd, skønt klar og overskuelig. Det kan undre, at han i så høj grad parafraserer den lettilgængelige artikel i stedet for at inddrage de mange andre interviews, essays og tekststeder (f.eks. forordet til den andrede seksualitetshistorie), hvor dette emne berøres. Der lægges heller ikke vægt på Foucaults specielle sandhedsbegreb, hans overordnede bestemmelser af viden og vi- denskaber og deres koblinger til magten. Endelig forekommer det mig problematisk i så høj grad at isolere og nærlæse en tekst, der klart har interview-status. Forskellen mellem interview og 'rigtig' tekst var jo ganske af gørende for Foucault.

Med essayet "De infame menneskers liv", Foucaults forord til en aldrig udgivet historisk kildesamling, har idéhistorikeren Jens Erik Kristensen fundet en agte perle, og hans efterfølgende udlægning af teksten, "De hverdagslige lidenskabers konfliktuelle italesættelse. Foucaults historier mellem æstetik og analyse" udgør efter min mening antologiens højdepunkt. Det drejer sig om en ganske bemarkelsesvardig Foucaulttekst, hvor filosoffen i en for ham usædvanlig 'personlig' tone bekender sig til sin æestetiske fascination af en særlig slags kildemateriale, nemlig dokumenterne omkring de usle personnager, der blev indespærret i franske interneringshuse i det 17. og 18. århundrede.

Det drejer sig om bønskrifter, som typisk familiemedlemmer, naboer m.fl. rettede direkte til Kongen, for at få besvarlige personnager, ballademagere, $\varnothing$ delande osv. fjernet og spærret inde. I hver af disse ultrakorte, farverige tekster skjuler der sig et orgie af had, lidenskaber, kampe og livstragedier, og Kristensen bemærker at "Foucaults fascination, hans 'lille mani' galder disse bønskrifters sporadiske, men retorisk $h \varnothing j-$ spændte og stærkt dramatiserende italesættelse af mere eller mindre banale hverdagslige konflikter og lidenskaber" (s. 170). De små tekster beskrives som tilfældige, anonyme, men virkelige 'livsdigte' med en egen 


\section{Anmeldelser}

skønhed og gru.

Kristensen boltrer sig veloplagt $i$ en analyse af denne tekst, som han ligesom Gilles Deleuze opfatter som ganske central. For Deleuze ligger dens betydning i, at den klart belyser Foucaults synlighedsfascination og visualitets $\emptyset$ konomi (de internerede blev et $\varnothing$ jeblik genstand for en 'magtens visualitet', en ultrakort, negativ 'berømmelse', hvor magten slår ned på dem med et lyn-blik, der i samme bevægelse oplyser og ødelægger dem); og den illustrerer Foucaults centrale tese om magtens "omvendte, nedadgående berømmelse": at fokus først og fremmest er på de underkastede, de "rene sub-jekter".

For Kristensen er teksten interessant, fordi den illustrerer en markant glidning i Foucaults æstetik: en interesseforskydning fra 60 'er-fasens interesse for modernistisk transgressionslitteratur til det hain kalder de historiske arkivers "modstandsæstetik", dokumentsamlingernes subversive moddiskurser. Foucault forlader i stigende grad den institutionaliserede 'litteratur' til fordel for virkelighedens marginaliserede diskurser: "Man kunne sige, at hans smag for de fiktive og transgressive momenter i dele af den moderne litteratur er blevet afløst af en smag for arkivernes historisk-diskursive spor af tragiske, men virkelig(e) eksistenser" (s. 180).

Denne glidning laser Kristensen sammen med en 'produktiv' apori i hele Foucaults tænkning, en slags historiegrafisk skizofreni, der præger hans værk: på den ene side hovedbestræbelsen på at skrive 'rene', neutrale analyser i hovedvarkerne, på den anden side 'marginalteksterne', hvor han besvarger uartikulerbarheden i "det udenfor" og uhåndgribeligheden i det forgangnes tragiske intensitet: "I begge tilfalde er der tale om måder at håndtere det historiografiske villkår, når man som Foucault har valgt at tage udgangspunkt i kulturelle og eksistentielle grænseerfaringer, men har indset, at man på den ene side ikke kan "overskride grænsen", og dog på den anden side ikke helt vil affinde sig med det som et vilkår" (s. 178). Den selvkritik Foucault i halvfjerdserne ytrer mod sin egen anvendelse af litteratur og galskab i tresserfasen som kontrapunktisk 'andethed', "myten om det udenfor", som han kalder det, resulterer således i en æstetisk nyorientering, 'grænsen' flyttes, om man vil, fra udvalgte transgressive litterære værker til virkelighedens og fortidens marginaler.

Kristensens redegørelse for udviklingen i Foucaults æstetik fra 60'ernes systematiske epistemologisk-arkaologiske unders $\varnothing$ gelser på den ene side og de transgressive litteraturfilosofiske og astetiske skrifter på den anden til 70-ernes genealogiske og magtanalytiske hovedværker på den ene side og de mere marginale, astetik-betonede historiskdokumentariske udgivelser på den anden er overordentlig tankevækkende, men det forekommer mig, at modsatningerne trakkes lidt vel hårdt op. Skotterne mellem lidenskab og videnskab var aldrig vandtatte hos Foucault, og også de 'tørre' hovedværker oplyses af poetiske glimt (den farverige skildring af middelalderen i Les mots et les choses, det blodige 'Damiens'-tableau der indleder Surveiller et punir f.eks.).

Det suggestive essay rammer ned i en 


\section{Anmeldelser}

spændende Foucault-problematik, som det ville have været interessant at forfølge ind i firserfasen. Opløses her endelig aporien mellem ' $k \varnothing l i g$ ' analyse og æstetisk idiosynkratisk påkaldelse, der tilsyneladende hidtil ikke kunne rummes i et og samme værk: er begrebet om 'eksistensæstetik' og den lystfyldte rejse tilbage til den antikke 'livskunst' den harmoniske pirouette, Foucault når at foretage før tæppefald? Har historien om den foucaultske splittelse en slags happy end med de 'glade', smukke og lettilgængelige værker om grækerne og romerne?

Dette tema berøres ikke i romanisten Knut Stene-Johansens korte essay om "Foucaults vandel" foranlediget af et forstudie til tredie bind af seksualitetshistorien, "At skrive sig selv", en undersøgelse af romernes konstruktion af selvet gennem skriftpraktikker fra 1983. Stene-Johansens tekst er et eklatant antiklimaks: Foucaults ironisering af romernes selv-dyrkelse er spildt på Stene-Johansen, der naivt moraliserer ud fra den romerske skriftpraksis i en ulideligt popularisende 'aktualisering'. At han ikke formår at lokalisere den lille Foucault-tekst inden for seksualitetshistorien kan ikke undre: han angiver, at tredie bind omhandler "grekernes interesse for "nødvendigheten av å være opptatt av seg selv"' (s. 204). Bindet handler om romerne. Derudover synes de helt afgørende forskelle mellem de romerske selv-praktikker og den senere kristne selv-ransagelse, Foucault-tekstens centrale pointe, ikke at være forstået. Teksten befinder sig markant under antologiens $\emptyset$ vrige niveau.
Generelt må det konkluderes, at Foucaults masker trods mangler indfrir sine løfter. Redigeringen kunne have været bedre, teksterne kunne have kommunikeret mere med hinanden, en del gentagelser være undgået, og oversættelsernes kvalitet er noget svingende (et mere mundret dansk havde været $\varnothing$ nskeligt frem for den slaviske bundethed til den franske original). Men i de bedste af artiklerne lykkes det at nuancere, dynamisere og mangfoldiggøre "den skandinaviske Foucault" (man savner dog litteraturhenvisninger herom!) i en udgivelse, der trods sin billige pris, er et stykke solidt bogarbejde. Foucaults masker demonstrerer, at selvom det fysiske 'ansigt' er forsvundet, er "den diskurs, der taler Foucault" mere levende end nogensinde. 